\title{
Genetic diversity of Norway spruce [Picea abies (L.) Karst.] in Romanian Carpathians
}

\author{
R. Gh. Radu, L. Al. Curtu, Gh. Spârchez, N. Șofletea
}

Radu Gh. R., Curtu Al. L., Spârchez Gh., Șofletea N., 2014. Genetic diversity of Norway spruce [Picea abies (L.) Karst.] in Romanian Carpathians. Ann. For. Res. 57(1): 19-29, 2014.

Abstract. The genetic diversity of Romanian most important coniferous tree species, the Norway spruce, was estimated by means of allozyme markers. A total of 695 adult trees sampled from eleven populations grouped in six mountainous areas in the Romanian Carpathians were analyzed. In three metapopulations (Maramureş, Postăvar and Parâng), to evaluate the influence of altitudinal gradient on genetic diversity, samples were collected from populations located at high and low altitude. At other location (Apuseni Mountains) we compared the narrow-crown biotype (Picea abies var. columnaris) and the pyramidal crown biotype (Picea abies var. pyramidalis) and explored the genetic structure of peat bog ecotype. By analyzing 7 enzyme systems and 12 enzyme coding loci, a total of 38 allelic variants have been detected. The mean value of polymorphic loci for the six sites was $86.1 \%$, ranging between $83.3 \%$ and $91.7 \%$ and the mean expected heterozygosity was 0.115 , resulting in a moderate level of genetic diversity. The highest genetic diversity $\left(H_{e}=0.134\right)$ was found in the narrow-crown spruce population. Apuseni metapopulation showed the highest genetic diversity $\left(H_{e}=0.125\right)$, being the most valuable for conservation of genetic resources. The small value of fixation index $\left(F_{S T}=0.009\right)$ indicates a low genetic differentiation between the six sites and AMOVA test revealed a very high level of genetic diversity within population (99\%). Comparative analysis of genetic parameters showed small differences between high and low altitude populations at each site, probably due to the neutral character of the markers analyzed and the effect of gene flow between gradiental populations. Keywords genetic diversity, Norway spruce, Picea abies, conservation, allozymes, Romanian Carpathians

Authors. Raul Gheorghe Radu, Lucian Alexandru Curtu, Gheorghe Spârchez, Neculae Şofletea (nic.sofletea@unitbv.ro) - University of Transilvania Braşov, Dept. of Forest Sciences, Şirul Beethoven - 1, Braşov - 500 123, Romania.

Manuscript received January 25, 2014; revised April 09, 2014; accepted April 16, 2014; online first April 17, 2014. 


\section{Introduction}

In view of climate change, genetic diversity is one of the most important factors that may contribute to the adaptability of species (Parmesan 2006, Thompson et al. 2009). The capacity to adapt of keystone species play a crucial role for the maintenance of a whole range of associated organisms. Norway spruce [Picea abies L. (Karst.)] is the major tree species of mountainous forest ecosystems in Europe. In Romanian Carpathians, Norway spruce is the dominant native forest species at elevations between 1200 and $1800 \mathrm{~m}$ (Feurdean et al. 2011), but scattered populations can be found until $500 \mathrm{~m}$ above sea level (Sofletea \& Curtu 2007). Currently, Norway spruce is the most used species in plantation forestry and plays an important role for carbon storage in the Carpathian Mountains (Dutcă et al. 2010).

Although in the last decade genetic diversity is estimated predominantly by means of DNA markers, allozymes still remain the marker of choice because of a series of advantages. Thus, besides being less expensive and relatively easy to be assessed, they reveal variation at functional genes (enzyme coding genes) and exhibit relatively high levels of polymorphism (Hamrick et al. 1992, Crawford 1989). The allozyme markers are useful for monitoring the genetic changes in the process of evolution (Luo et al. 2005) and for describing geographical patterns of variation that are useful in gene conservation (Vicario et al. 1995). By revealing the genetic diversity between individuals and among populations, these markers are essential for the development of effective strategies for sustainable management and conservation (Luo et al. 2005).

The genetic diversity of Norway spruce across Europe has been intensively studied by means of allozyme markers. These studies revealed valuable information about the genetic structure mainly in central part of Europe (Giannini et al. 1991, Geburek 1999, MullerStarck 1995, Goncharenko et al. 1995, Kon- nert 2009), but also in the northern and Baltic states (Lundkvist 1979, Krutovskii \& Bergmann 1995, Korshikov \& Privalikhin 2007, Kravchenko et al. 2008, Sabor et al. 2013). In Romania, studies on genetic diversity of Norway spruce with allozyme makers have been initiated in Postăvar Mountain (Stănescu \& Şofletea 1992). Recent studies characterized the genetic structure of Norway spruce in the northern part of its natural range in Romania (Teodosiu 2011). Moreover, twenty provenances of Norway spruce have been examined by means of allozyme markers in a field trial (Teodosiu 2009).

This paper is aimed at assessing the genetic diversity of Norway spruce in populations included in NATURA 2000 network across Carpathian Mountains. The geographic distribution of sampled populations allowed an evaluation of overall genetic diversity of this species in the Romanian Carpathians. A second goal of the present study was to evaluate the influence of altitudinal gradient on genetic diversity by comparing high and low altitude populations at the same site. Another objective was to compare allozyme genetic structure of two biotypes Picea abies var. columnaris and Picea abies var. pyramidalis, and also to explore the genetic structure of a peat bog ecotype.

\section{Material and methods}

\section{Study site and sampling}

Eleven populations of Norway spruce distributed in six NATURA 2000 sites along Carpathian Mountains were sampled (Fig. 1 and Table 1). At three sites (PRG, MMS and PST), samples were collected from two populations situated at low and high altitude, respectively. The two populations from the same mountainous area were considered as one metapopulation because they suppose to communicate with each other more intensely than distant 
populations (Hanski 1991, Hogan 2011). Another metapopulation (APS) included samples of pyramidal crown individuals (Picea abies var. pyramidalis), narrow-crown individuals (P.a. var. columnaris) and peat bog ecotype. In total 695 adult trees were analyzed, the sampling size per population ranging between 50 and 100 individuals, except for narrow-crown spruce population APS-2 (30 trees). To examine the allozyme genetic structure, twigs with winter buds were collected from trees located at $30-50 \mathrm{~m}$ from each other.

\section{Allozyme analysis}

Standard methods were used for electrophoresis and staining (Konnert \& Maurer 2004). The horizontal electrophoresis was performed for seven enzyme systems coded by 12 loci: Phosphoglucose-isomerase (PGI) E.C.5.3.1.9. - two loci, Aspartataminotransferase (GOT)
E.C.2.6.1.1. - three loci, Glutamatdehydrogenase (GDH) E.C.1.4.1.2 - one locus, Formiatdehydrogenase (FDH) E.C.1.2.1.2 - one locus, Phosphoglucomutase (PGM) E.C.2.7.5.1. - two loci, Shikimatdeydrogenase (SKDH) E.C.1.1.1.25. - one locus and Isocitratdehydrogenase (IDH) E.C. 1.1.1.42 - two loci.

\section{Data analysis}

The genetic diversity within populations was evaluated by calculating the following parameters: percentage of polymorphic loci (PPL\%), number of alleles per locus $(\mathrm{Na})$, effective number of alleles per locus $(\mathrm{Ne})$, expected heterozygosity (He), observed heterozygosity (Ho) and fixation index (F). All these parameters were calculated using GenAlEx 6.2 software (Peakall \& Smouse 2006). Allelic richness, which is one of the most commonly reported measures of genetic variation (Leberg 2002),

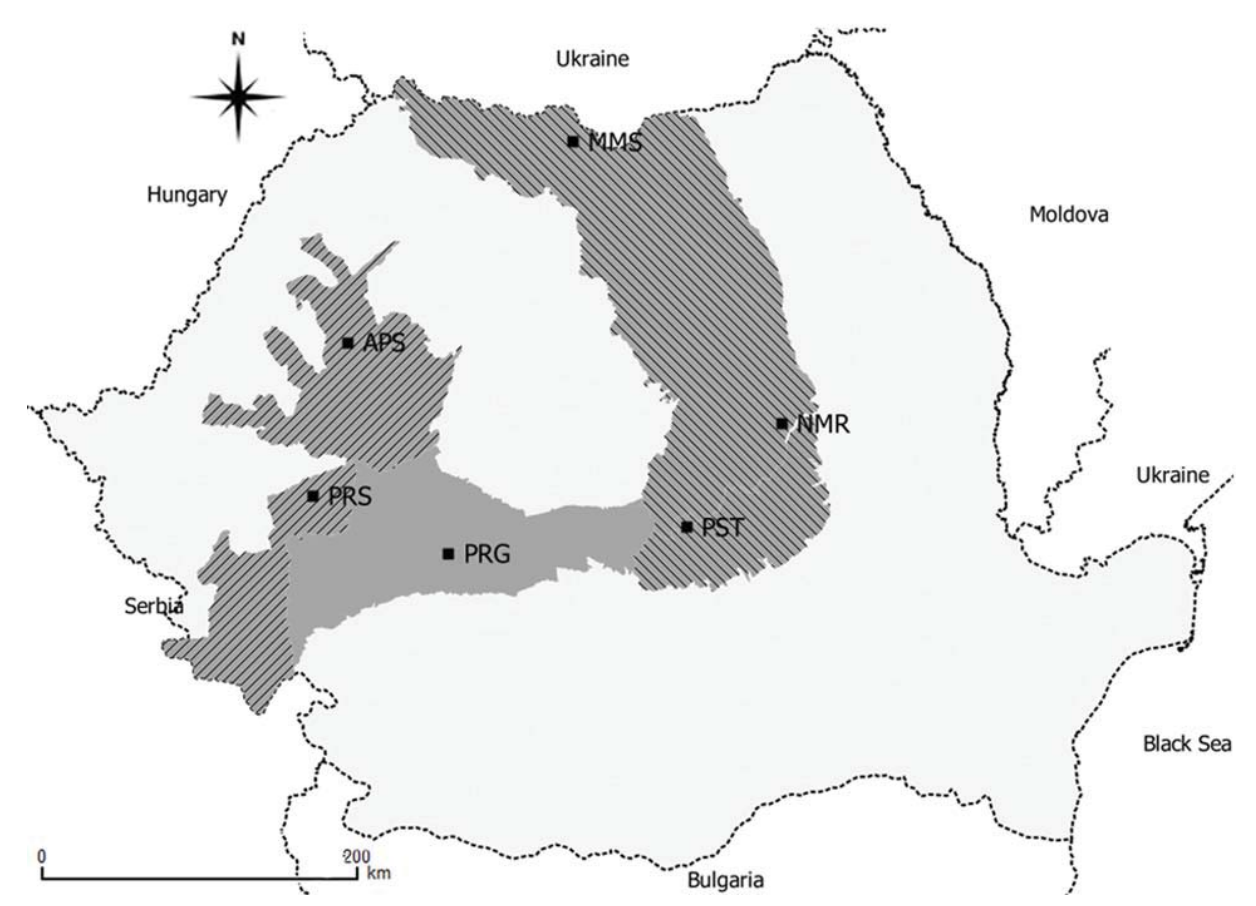

Figure 1 Location of Norway spruce populations. The shadow area represents the Carpathian Mountains

Note. Abbreviations: MMS - Maramures, NMR - Nemira, PST - Postăvar, PRG - Parâng, PRS - Poiana Ruscă, APS - Apuseni.

Eastern Carpathians Southern Carpathians Western Carpathians 
Table 1 Description of sampled populations

\begin{tabular}{|c|c|c|c|c|c|c|c|}
\hline $\begin{array}{l}\text { Population } \\
\text { - P/ Metpo- } \\
\text { pulation - M }\end{array}$ & $\begin{array}{l}\text { Population } \\
\text { and } \\
\text { abbreviation }\end{array}$ & Location & Latitude & Longitude & $\begin{array}{l}\text { Average } \\
\text { altitude } \\
\text { (m) }\end{array}$ & $\begin{array}{l}\text { Average } \\
\text { annual* } \\
\text { temperature } \\
\left({ }^{\circ} \mathrm{C}\right)\end{array}$ & $\begin{array}{l}\text { Sample } \\
\text { size }(N)\end{array}$ \\
\hline \multirow{3}{*}{$\begin{array}{l}\text { Apuseni - M } \\
\text { (APS) }\end{array}$} & $\begin{array}{l}\text { Peat bog } \\
\text { ecotype } \\
\text { (APS-1) }\end{array}$ & \multirow{3}{*}{$\begin{array}{l}\text { Western } \\
\text { Carpathians }\end{array}$} & $46^{\circ} 36^{\prime} 5.61{ }^{\prime \prime} \mathrm{N}$ & $22^{\circ} 46^{\prime} 25.09^{\prime \prime} \mathrm{E}$ & 1210 & 5.1 & 60 \\
\hline & $\begin{array}{l}\text { P.a. var. } \\
\text { columnaris } \\
\text { (APS-2) } \\
\end{array}$ & & $46^{\circ} 35^{\prime} 1.51 ” \mathrm{~N}$ & $22^{\circ} 45^{\prime} 45.19^{\prime \prime} \mathrm{E}$ & 1390 & 5.0 & 30 \\
\hline & $\begin{array}{l}\text { P.a. var. } \\
\text { pyramidalis } \\
\text { (APS-3) }\end{array}$ & & $46^{\circ} 36^{\prime} 42.02^{\prime \prime} \mathrm{N}$ & $22^{\circ} 45^{\prime} 28.554^{\prime \prime} \mathrm{E}$ & 1300 & 4.0 & 60 \\
\hline \multirow{2}{*}{$\begin{array}{l}\text { Parâng - M } \\
\text { (PRG) }\end{array}$} & $\begin{array}{l}\text { Parâng high } \\
\text { altitude } \\
\text { (PRG-1) }\end{array}$ & \multirow{2}{*}{$\begin{array}{l}\text { Southern } \\
\text { Carpathians }\end{array}$} & $45^{\circ} 24^{\prime} 45.79^{\prime \prime} \mathrm{N}$ & $23^{\circ} 38^{\prime} 17.66^{\prime \prime} \mathrm{E}$ & 1800 & 3.2 & 60 \\
\hline & $\begin{array}{l}\text { Parâng low } \\
\text { altitude } \\
\text { (PRG-2) }\end{array}$ & & $45^{\circ} 24^{\prime} 56.77^{\prime \prime} \mathrm{N}$ & $23^{\circ} 37^{\prime} 39.72^{\prime \prime} \mathrm{E}$ & 1370 & 4.6 & 60 \\
\hline \multirow{2}{*}{$\begin{array}{l}\text { Postăvar - M } \\
\text { (PST) }\end{array}$} & $\begin{array}{l}\text { Postăvar } \\
\text { high altitude } \\
\text { (PST-1) }\end{array}$ & \multirow{2}{*}{$\begin{array}{l}\text { Eastern } \\
\text { Carpathians } \\
\end{array}$} & $45^{\circ} 34^{\prime} 10.11^{\prime \prime} \mathrm{N}$ & $25^{\circ} 33^{\prime} 52.78^{\prime \prime} \mathrm{E}$ & 1720 & 2.6 & 50 \\
\hline & $\begin{array}{l}\text { Postăvar low } \\
\text { altitude } \\
\text { (PST-2) }\end{array}$ & & $45^{\circ} 36^{\prime} 33.40^{\prime \prime} \mathrm{N}$ & $25^{\circ} 32^{\prime} 35.70^{\prime \prime} \mathrm{E}$ & 920 & 6.0 & 50 \\
\hline \multirow{2}{*}{$\begin{array}{l}\text { Maramureş } \\
\text { - M (MMS) }\end{array}$} & $\begin{array}{l}\text { Maramureş } \\
\text { high altitude } \\
\text { (MMS-1) }\end{array}$ & \multirow{2}{*}{$\begin{array}{l}\text { Eastern } \\
\text {-Carpathians }\end{array}$} & $47^{\circ} 45^{\prime} 47.08^{\prime \prime} \mathrm{N}$ & $24^{\circ} 37^{\prime} 39.40^{\prime \prime} \mathrm{E}$ & 1380 & 4.0 & 82 \\
\hline & $\begin{array}{l}\text { Maramureş } \\
\text { low altitude } \\
\text { (MMS-2) }\end{array}$ & & $47^{\circ} 45^{\prime} 8.30^{\prime \prime} \mathrm{N}$ & $24^{\circ} 37^{\prime} 46.52^{\prime \prime} \mathrm{E}$ & 850 & 5.8 & 78 \\
\hline $\begin{array}{l}\text { Nemira - P } \\
\text { (NMR) }\end{array}$ & $\begin{array}{l}\text { Nemira } \\
\text { (NMR) }\end{array}$ & $\begin{array}{l}\text { Eastern } \\
\text { Carpathians }\end{array}$ & $46^{\circ} 09^{\prime} 9.77^{\prime \prime} \mathrm{N}$ & $26^{\circ} 21^{\prime} 2.48^{\prime \prime} \mathrm{E}$ & 1300 & 4.2 & 100 \\
\hline $\begin{array}{l}\text { Poiana Ruscă } \\
- \text { P (PRS) }\end{array}$ & $\begin{array}{l}\text { Poiana } \\
\text { Ruscă (PRS) }\end{array}$ & $\begin{array}{l}\text { Western } \\
\text { Carpathians }\end{array}$ & $45^{\circ} 43^{\prime} 18.19 ” \mathrm{~N}$ & $22^{\circ} 31^{\prime} 28.56^{\prime \prime} \mathrm{E}$ & 900 & 7.1 & 65 \\
\hline
\end{tabular}

Note. * Average annual temperature have been extracted from www.worldclim.org.

which designates independent of its sample size the number of different alleles from each population and also on average in metapopulations, was calculate using FSTAT 2.9.3.2. (Goudet 1995). Because the small samples are expected to have fewer alleles and an unequal number of samples can distort the interpretation of allelic richness values, for analysis of this parameter the method of rarefaction was used (Kalinowski 2004). To assess standard deviation from Hardy-Weinberg equilibrium a $\chi^{2}$ test was performed using POPGENE 1.3.1 software (Yeh \& Yang 1999). The genetic difference between populations were examined by calculating the $\mathrm{F}_{\mathrm{ST}}$ value to all loci and to all populations and the value of $\mathrm{F}_{\mathrm{ST}}$ was tested by calculating $P$ value at 10000 permutations through ARLEQUIN ver. 3.5.1.2. (Excoffier et al. 2005). To partition genetic diversity among populations AMOVA was used. Mantel test 
was used to test for the existence of geographic structure of genetic diversity; metapopulations were considered as a single population for AMOVA and Mantel test. To show the genetic relationships among populations the UPGMA dendrogram was constructed based on Cavalli-Sforza genetic distances. The genetic correlations between populations were tested by using 1000 bootstraps. The UPGMA dendrogram was constructed with POPULATION 1.2.3.2 software (Langella 1999).

\section{Results}

The analysis of the seven enzyme systems revealed 38 allelic variants for 12 enzymecoding loci (Supporting information). Out of these, $15(39.4 \%)$ are common to all populations. The highest number of allelic variants (5) was found at the Skdh-A locus. Five alleles have been observed only in four populations (Gdh-A-4 in the APS-2 population, Idh-A-4 and Skdh-A-5 in the PRS population, Pgi-A3 in the high elevated population PST-1 and allele Idh-B-2 in the low altitude population PST-2), but their frequency was very small (0.008 to 0.017$)$.

The mean value of polymorphic loci for the six sites was $86.1 \%$, ranging between $83.3 \%$ and $91.7 \%$ (Table 2). The lowest value of polymorphism $(58.3 \%)$ was observed for the narrow-crown spruce (APS-2 population) and in the high altitude population of Parâng Mountains (PRG-1). Due to the different number of samples analyzed per population, the values for the average number of alleles per locus $\left(N_{a}\right)$ and the effective number of alleles $\left(N_{e}\right)$ are not comparable. Therefore, allelic richness (A) values was calculated and the average value for all six mountainous areas analyzed was 1.864. The highest value for allelic richness

Table 2 Values of genetic parameters per population

\begin{tabular}{|c|c|c|c|c|c|c|c|c|c|}
\hline Locations & Population & $N$ & $P P L(\%)$ & $N_{a}$ & $N_{e}$ & A & $H_{o}$ & $H_{e}$ & $F$ \\
\hline \multirow{4}{*}{ APS } & APS-1 & 60 & $75.0 \%$ & 2.250 & 1.205 & 1.944 & 0.126 & 0.122 & -0.036 \\
\hline & APS-2 & 30 & $58.3 \%$ & 2.000 & 1.237 & 2.000 & 0.150 & 0.134 & -0.082 \\
\hline & APS-3 & 60 & $83.3 \%$ & 2.250 & 1.176 & 1.922 & 0.123 & 0.117 & -0.039 \\
\hline & APS & 150 & $91.7 \%$ & 2.667 & 1.205 & 1.955 & 0.130 & 0.125 & -0.031 \\
\hline \multirow{3}{*}{ PRG } & PRG-1 & 60 & $58.3 \%$ & 1.833 & 1.178 & 1.665 & 0.113 & 0.106 & -0.042 \\
\hline & PRG-2 & 60 & $75.0 \%$ & 2.083 & 1.218 & 1.816 & 0.133 & 0.126 & -0.039 \\
\hline & PRG & 120 & $83.3 \%$ & 2.333 & 1.200 & 1.740 & 0.123 & 0.118 & -0.030 \\
\hline \multirow{3}{*}{ PST } & PST-1 & 50 & $83.3 \%$ & 2.000 & 1.175 & 1.870 & 0.109 & 0.106 & -0.031 \\
\hline & PST-2 & 50 & $66.7 \%$ & 2.000 & 1.176 & 1.743 & 0.098 & 0.096 & -0.016 \\
\hline & Average & 100 & $91.7 \%$ & 2.333 & 1.175 & 1.807 & 0.104 & 0.102 & -0.017 \\
\hline \multirow{3}{*}{ MMS } & MMS-1 & 82 & $83.3 \%$ & 2.083 & 1.185 & 1.810 & 0.110 & 0.112 & -0.013 \\
\hline & MMS-2 & 78 & $75.0 \%$ & 2.250 & 1.203 & 1.912 & 0.119 & 0.120 & -0.016 \\
\hline & Average & 160 & $91.7 \%$ & 2.500 & 1.194 & 1.861 & 0.114 & 0.116 & -0.012 \\
\hline NMR & NMR & 100 & $75.0 \%$ & 2.333 & 1.187 & 1.923 & 0.119 & 0.116 & -0.029 \\
\hline \multirow[t]{3}{*}{ PRS } & PRS & 65 & $83.3 \%$ & 2.250 & 1.188 & 1.897 & 0.121 & 0.112 & -0.037 \\
\hline & \multirow{2}{*}{ Average } & $63.18^{*}$ & $74.2 \% *$ & $2.121 *$ & $1.193 *$ & $1.864 *$ & $0.120^{*}$ & $0.115^{*}$ & $-0.033^{*}$ \\
\hline & & $115.83^{* *}$ & $86.1 \% * *$ & $2.403^{* *}$ & $1.192 * *$ & $1.864 * *$ & $0.119^{* *}$ & $0.115^{* *}$ & $-0.026 * *$ \\
\hline
\end{tabular}

Note. * mean values for all 11 populations; ** mean values for the six sites; $N$ - sample size; $P P L \%$ - percentage of polymorphic loci; $N_{a}$ - number of allele per locus; $N_{e}$ - effective number of allele per locus; $A$ - allelic richness; $H_{o}$ - observed heterozygosity; $H_{e}$ - observed heterozygosity; $F$ - fixation index. 
was registered in APS $(A=1.955)$ followed by $\operatorname{NMR}(A=1.923)$, and the lowest in PRG $(A=$ $1.740)$, and does not indicate a clear pattern of altitudinal influence. Overall expected heterozygosity $\left(H_{e}\right)$ was 0.115 . The highest value was observed in APS $\left(H_{e}=0.125\right)$ and the lowest in PST $\left(H_{e}=0,102\right)$. The same trend observed for allelic richness (lower at high altitude in PRG-1 and MMS-1 populations) is also valid for expected heterozygosity. In all populations the mean value of fixation index showed a small deficit of homozygote individuals $(F=$ -0.033) and this situation persists when populations in a site are considered as metapopulation $(F=-0.026)$. The highest deviation from Hardy-Weinberg equilibrium $(8.2 \%$ deficit of homozygotes) was recorded in the narrowcrown type population APS-2.

Analyses of populations sampled from different altitudinal levels reveal a higher level of heterozygosity and allelic richness in two locations (MMS and PRG) at low altitudes (Table 2). In contrast, in the PST metapopulation, the low altitudinal population (PST-2) had the lowest genetic diversity among all populations.

As in the case of allelic richness, populations studied on different altitudinal gradient from the same sites showed contrasting pattern on genetic heterozygosity.

The comparative analysis of different bio-

Table 3 Fst values at each enzyme coding locus

\begin{tabular}{lll}
\hline Locus & $F_{S T}$ & $P$ - value \\
\hline Fdh-A & 0.0043 & 0.40 \\
Gdh-A & 0.0025 & 0.60 \\
Got-A & 0.0050 & 0.31 \\
Got-B & 0.0089 & 0.06 \\
Got-C & 0.0002 & 0.90 \\
Idh-A & 0.0035 & 0.48 \\
Idh-B & 0.0056 & 0.25 \\
Pgi-A & 0.0021 & 0.73 \\
Pgi-B & 0.0188 & 0.00 \\
Pgm-A & 0.0175 & 0.00 \\
Pgm-B & 0.0079 & 0.08 \\
Skdh-A & 0.0129 & 0.00 \\
Mean & 0.0092 & 0.00 \\
\hline
\end{tabular}

types and ecotypes reveal a smaller heterozygosity and allelic richness values to normal crown spruce populations (Picea abies var. pyramidalis) compared with narrow-crown biotype and peat bog ecotype. The highest genetic diversity value was observed in the narrow-crown biotype population (Picea abies var. columnaris).

The AMOVA test showed that only $1 \%$ of the genetic diversity is due to differences between populations. Mean $F_{S T}$ value $(0.0092)$, which is based on the variance of allele frequencies between populations, also showed small differences between populations at the 12 loci analyzed. The Pgi-B, Pgm-A and Skdh-A loci showed the highest degree of differentiation (Table 3).

In the hierarchical UPGMA dendrogram based on Cavalli-Sforza genetic distances two clusters and three subclusters were generated (Fig. 2). Five populations (PRG-1, PRG-2, APS-1, APS-2 and PRS) form a western group. The other group, except for APS-3 population, is geographically located in the eastern part of the Romanian Carpathian chain. The two populations from Postăvar Mountain are clustered together in a separate group. However, by comparing the genetic and geographic distances among the six sites trough Mantel test no correlation between genetic and geographic distances have been found.

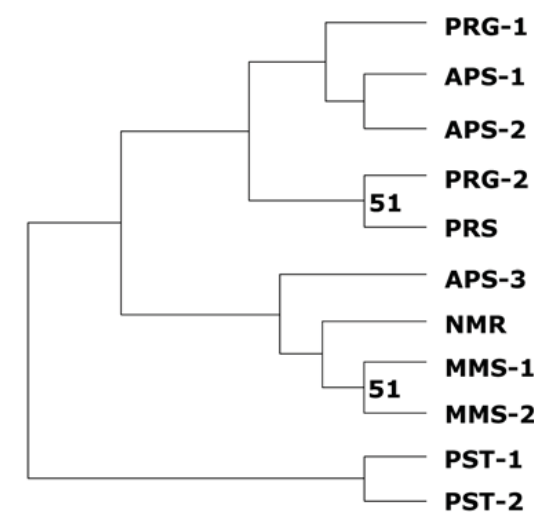

Figure 2 UPGMA tree using Cavalli-Sforza genetic distances between Norway spruce populations (only bootstrap values over $50 \%$ are reported) 


\section{Discussion}

The level of genetic diversity observed in Norway spruce populations from Carpathians Mountains is similar to that reported for conifers (Hamrick et al. 1992). However, our values are smaller than those reported for Norway spruce stands from northern Romania (Teodosiu 2009, Teodosiu 2011) and in populations from Ukrainian Carpathians (Korshikov \& Privalikhin 2007). Nevertheless, the comparative assessment with other studies should be done with caution because each one relies on a different set of markers. Although the number of loci used in our study to describe the Norway spruce diversity is slightly smaller than other studies (Lagercrantz \& Ryman 1990, Krutovskii \& Bergmann 1995), the proportion of polymorphic loci and the number of alleles per locus did not differ substantially. As in other studies, the highest amount of genetic difference was observed within populations and it was reduced among populations (Lewandowki \& Burczyk 2002, Korshikov \& Privalikhin 2007, Goncharenko et al. 1995, Kravchenko et al. 2008).

Five alleles were identified only in four populations. However, these have also been reported in some populations of Norway spruce in Central Europe. Thus, the rare allele found in the APS metapopulation (Gdh-A-4) was also reported in eight from nine populations studied in the Ukrainian Carpathians (Korshikov \& Privalikhin 2007). Also, in an IUFRO program for testing 15 provenances, the allele Skdh-A5 identified in the PRS population was scored in one provenance and Idh-B-2 from PRS was identified in four provenances (Kannenberg \& Gross 1999). As in other populations from Europe (e.g. from Switzerland - Muller-Starck 1995) especially Skdh-A, but also Pgm-B and Fdh-A loci indicate small geographical trends of genetic variation. We consider that the presence of such two rare alleles has contributed to separate position of PST metapopulation in UPGMA dendrogram constructed for the pop- ulations analyzed.

The number of allele per locus $\left(N_{a}\right)$ are higher than in other Norway spruce populations studied in Romania (Teodosiu 2011) in nine populations from Obcinele Bucovinei (Eastern Romanian Carpathians). However, such similarities for the average number of alleles per locus resulted from our data were also reported by Korshikov \& Privalikhin (2007) for populations analyzed in Ukrainian Carpathians and in populations from Alps and Dinaric Alps (Giannini et al. 1991, Ballian et al. 2007). Higher values of $N_{a}$, up to 2.5 , were found in populations of Norway spruce from Switzerland and in northern part of Europe, in Ukraine, Sweden, and Russia (Muller-Starck 1995, Krutovskii \& Bergmann 1995, Goncharenko et al. 1995).

On the other hand, it is notable that the highest values for both parameters allelic richness $(A=2.0)$ and genetic diversity are showed in the narrow-crown spruce population APS-2. These data show the high genetic value of narrow-crown spruce population from Apuseni Mountains. Moreover, in APS metapopulation allelic richness and expected heterozygosity have also higher values for normal crown population and also in the peat bog population. Consequently, these genetic data show that the APS metapopulation is the most valuable for conservation of genetic resources.

Overall, expected heterozygosity $\left(H_{e}=\right.$ 0.115 ) is similar to the average value found in 70 populations from Europe natural range of Norway spruce (Lagercrantz \& Ryman 1990) and in the Sumava Mountains (Mánec 1999). Slightly lower values of genetic diversity than in our study have been found in Slovakian Carpathians, (Krajmerova \& Longauer 2000), but higher in Serbia (Milovanovic \& Sijacić-Nikolic 2010), and Bosnia (Oršanić et al. 2007, Ballian et al. 2007), and also in populations from Italy, Germany, Sweden, Russia or Latvia (Krutovsky \& Bergmann 1995, Goncharenco et al. 1995). Corroborated with data of our study, the values determined by allozyme markers in the Ukraine (Korshikov \& 
Privalikhin 2007) and Slovakian Carpathians (Mánec 1999) suggest a lower genetic diversity of Norway spruce in this area. This might be linked to the reduced size of these populations during the last glacial period. This hypothesis was discussed by Kremer (1994) for the northern Europe populations whose glacial refugia have been in southern areas. Certainly, the genetic structure of Norway spruce in Romanian Carpathians was influenced by the history of these populations (e.g. postglacial migration), as has been shown in other areas (MullerStarck 1995). The existence of a glacial refugia in Carpathians Mountains was evidenced by showing an early spreading of Norway spruce in Romania (11,000-10,500 yr BP) from sites located in northwestern and northern parts of Carpathians, with a possibility of presence of a glacial refugia in southern Carpathians, in the Transylvania today area (Feurdean et al. 2011). The highest genetic diversity that resulted in APS metapopulation, in the central Transilvania, seems to be an indication for the existence of glacial refugia in this area, but this requires consistent genetic and palynological investigations.

On the other hand, as in other studies (Lewandowki \& Burczyk 2002, Korshikov \& Privalikhin 2007, Goncharenko et al. 1995, Kravchenko et al. 2008) only a small proportion $(1 \%)$ of genetic diversity is distributed among populations. Moreover, the value of the fixation index $\left(F_{S T}=0.0092\right)$, which is a measure of population differentiation due to genetic structure, is even lower than that reported by Korshikov and Privalikhin (2007) in the Ukrainian Carpathians $\left(F_{S T}=0.017\right)$. Higher values of genetic differentiation among populations were also reported in studies from Russia, Slovakia, Italia and Serbia (Kravchenko et al. 2008, Krajmerova et al. 2000, Giannini et al. 1991, Milovanovic \& Sijacić-Nikolic 2010). The $F_{S T}$ values indicate that the main contribution to differentiation genetic structure of populations was made by loci Pgi-B, Pgm-A and Skdh-A.
Although higher values of genetic distances were registered between populations from higher distances, the results of Mantel test did not confirm isolation by distance hypothesis. Otherwise, the lack of spatial differentiation between populations are characteristic to conifers (Giannini et al. 1991) and indicate high outcrossing rate, fecundity and gene flow across the wide continuous distribution area; high density in Norway spruce populations is acting to reduce the influences of genetic drift (Krutovskii \& Bergmann 1995). In fact, in our study the Mantel test had slightly higher values when performed between metapopulations, in contrast to the analysis for the eleven populations, which indicate a small geographic trend.

The small values for genetic diversity and allelic richness in the low altitude population PST-2 may be the result of human interventions (deforestation and planting). Therefore, this part of the PST metapopulation shall not be considered for the conservation of genetic resources of Norway spruce. On the other hand, the high value of genetic diversity observed in the low-level populations from the MMS and PRG is consistent with some data provided in the literature (Muller-Starck 1995, Curtu et al. 2009), but other studies indicate no variation allele frequency patterns along altitude or latitude in Norway spruce populations, particularly in a small geographical region (Konnert 1991, Korshikov \& Privalikhin 2007). If we accept the lack of total neutrality of allozyme loci, an idea that is supported in some papers (Bush \& Smouse 1992, Sequeira et al. 1997, Sulkowska 2012), we can invoke the selective environmental pressure effect in determining the less diversity in high-altitude populations. In addition, concerning the narrow-crown spruce in APS-2 population, which is a biotype that reveals a very good resistance to winds and heavy snow (Pârnuță 2008), its high genetic diversity could be linked to a specificity of mating system in combination with the natural selection pressure that preserves a 
high level of heterozygosity. Phenotypic variation was also higher for narrow-crown spruce populations from Finland, compared with pyramidal crown (Zubizarreta et al. 2009).

\section{Conclusions}

Our study revealed a moderate level of genetic diversity, which is consistent with other studies on Norway spruce across its natural range. The high value of the heterozygosity obtained for Apuseni Mountains recommends this metapopulation as a valuable center for dynamic conservation of genetic resources in Romania. On the contrary, the low level of genetic diversity and allelic richness in Postavarul low elevation population call into question the naturalness and the conservation value of this population. On the other hand, although the level of genetic diversity in Poiana Rusca population is slightly lower than the average, the geographical isolation from the rest of the populations is a good reason to preserve this gene pool in the Carpathians area. A very high amount of genetic variation was within populations, resulting a very low value of the fixation index $\left(F_{S T}\right)$ and a high level of gene flow in an evolutionary perspective. The level of genetic diversity in populations of different altitudinal levels did not suggest a significant influence of altitude. Consequently, the set of markers used do not provide conclusive evidence in this regard. The high genetic diversity revealed in Apuseni Mountains for the narrowcrown biotype (Picea abies var. columnaris) and also for the peat bog ecotype is an argument for their high adaptive value.

\section{Acknowledgements}

The research was partly funded by the Partnership CONBIODIV 31-015/2007. We thank two anonymous reviewers for constructive comments on the manuscript.

\section{References}

Ballian D., Bogunić F., Božič G., 2007. Genetic variability of Norway spruce (Picea abies (L.) Karst.) in the Bosnian part of the dinaric mountain range. Sumarski list 131(5-6): 237-246.

Bush R.M., Smouse P.E., 1992. Evidence for the adaptive significance of allozymes in forest trees. New Forests 6 : 179-196. DOI: 10.1007/BF00120644.

Crawford D.J., 1989. Enzyme electrophoresis and plant systematics. In: D. E. Soltis, P. S. Soltis [eds.]: Isozymes in plant biology 146-164, Dioscorides Press, Portland, Oregon, USA.

Curtu L.A., Şofletea N., Radu R., Bacea A., Abrudan I.V., Butiuk-Keul A., Farcas S., 2009. Allozyme variation of coniferous tree species from Maramures Mountains, Romania. Notulae Botanicae Horti Agrobotanici ClujNapoca 37(2): 245-251.

Dutcă I., Abrudan I.V., Stăncioiu P.T., 2010. Biomass conversion and expansion factors for young Norway spruce (Picea abies (L.) Karst.) Trees Planted on Non-Forest Lands in Romania. Notulae Botanicae Horti Agrobotanici Cluj-Napoca 38(2): 286-292.

Excoffier L., Laval G., Schneider S., 2005. Arlequin version 3.0: An integrated software package for population genetics data analysis. Evolutionary Bioinformatics Online 1: 47-50.

Feurdean A., Tanțău I., Fărcaş S., 2011. Holocene variability in the range distribution and abundance of Pinus, Picea abies, and Quercus in Romania; implications for their current status. Quaternary Science Reviews Volume 30 (21-22): 3060-3075. DOI: 10.1016/ j.quascirev.2011.07.005.

Geburek T., 1999. Genetic variation of Norway spruce (Picea abies (L.) Karst.) populations in Austria. Macrospatial aloozyme patterns of high elevation populations. Forest Genetics 6(3): 201-211.

Giannini R., Morgante M., Vendramin G.G., 1991. Allozyme variation in Italian populations of Picea abies (L.) Karst. Silvae Genetica 40 (3/4): 160-166.

Goncharenko G.G., Zadeika I.V., Birgelis J.J., 1995. Genetic structure, diversity and differentiation of Norway spruce (Picea abies (L.) Karst.) in natural populatins of Latvia. Forest Ecology and Management 72 1): 31-38.

Goudet J., 1995. FSTAT Version 1.2. A computer program to calculate F-statistics. Journal of Heredity 86 (6): 485 486.

Hamrick J.L, Godt M.J.V., Sherman-Broyles S.L., 1992. Factors influencing levels of genetic diversity in woody plant species. New Forest 6(1-4): 95-124. DOI: 10.1007/BF00120641.

Hanski I., 1991. Metapopulation dynamics: grief history and conceptual domain. Biological Journal of Linnean Society 4: 3-16. DOI: 10.1111/j.1095-8312.1991. tb00548.x.

Hogan C. M. 2011. Metapopulation. Retrieved from http:// www.eoearth.org/view/article/171093. 
Kalinowski S.T., 2004. Counting alleles with rarefaction: Private alleles and hierarchical sampling designs. Conservation Genetics 5(4): 539-543. DOI: 10.1023/B: COGE.0000041021.91777.1a.

Kannenberg N., Gross K., 1999. Allozymic variation in some Norway spruce populations of the international IUFRO provenance-testing Programe of 1964/1968. Silvae Genetica 48 (5): 209-217.

Konnert M., 1991. Vergleich der genetischen struktur verschiedener generationen zweier naturlich verjungter Fichtenbestande des Schwarzwaldes. Silvae Genetica 40(2): 60-65

Konnert M., Maurer, W., 2004. Isoenzymuntersuchungen bei Fichte (Picea abies). Anleitungen zur Trennmethodik und Auswertung der Zymogramme [Instructions for separation methodology and analysis of the zimograms for Picea abies]. Bayerrisches Amt fur forstiche Saatund Pflanzenzucht: 1-22.

Konnert M., 2009. Genetic variation of Picea abies in southern Germany as determined using isozyme and STS markers. 61 supplement: 131-136.

Korshikov I.I., Privalikhin S.N., 2007. Genetic Structure of Populations of Norway Spruce (Picea abies (L.) Karst.) from Ukrainian Carpathians. Russian Journal of Genetics 43(12): 1364-1372. DOI: 10.1134/ S1022795407120058.

Krajmerová D., Longauer R., 2000. Genetická diverzita smreka obyčajného na Slovensku [Genetic diversity of Norway spruce in Slovakia]. Lesnícky Časopis 46(3): 273-286.

Kravchenko A.N., Larionova A.Ya., Milyutin L.I., 2008. Genetic polymorphism of Siberian Spruce (Picea obovata Ledeb.) in middle Siberia. Russian Journal of Genetics 44(1): 35-43. DOI: 10.1134/S1022795408010055.

Kremer A., 1994. Diversité génétique et variabilité des caractères phenitypiques ches les arbres forestiers. Genetics Selection Evolution 26, Suppl.1: 105-123. DOI: 10.1186/1297-9686-26-S1-S105.

Krutovskii K.V., Bergmann F., 1995. Introgressive hybridization and phylogenetic relationship between Norway, Picea abies (L.) Karst., and Siberian, P. obovata Ledeb., spruce species studied by isozyme loci. Heredity 74(5): 464-480. DOI: 10.1038/hdy.1995.67.

Lagercrantz U., Ryman N., 1990. Genetic structure of Norway spruce (Picea abies (L.) Karst.): Concordance of Morphological and Allozymic Variation. Evolution 44(1): 38-53. DOI: 10.2307/2409523.

Langella O., 1999. Population genetic software 1.2.31. free software foundation, Boston. Avaible on http//bioinformatics.org.

Leberg P.L., 2002. Estimating allelic richness: Effects of sample size and bottlenecks. Molecular Ecology 11(11): 2445-2449. DOI: 10.1046/j.1365-294X.2002.01612.x.

Lewandowski A., Burczyk J., 2002. Allozyme variation of Picea abies in Poland. Scandinavian Journal of Forest Research 17 (6): 487-494. DOI: 10.1080/0282758026 0417134.

Lundkvist K., 1979. Allozyme frequency distribution in four Swedish populations of Norway spruce (Picea abies (L.) Karst.). - Hereditas 90(1): 127-143. DOI: 10.1111/j.1601-5223.1979.tb01300.x.

Luo J., Wang Y., Karpelainen H., Li C., 2005. Allozyme variation in natural populations of Picea asperata. Silva Fennica 39(2): 167-176.

Mánek J., 1999. Genetic structure of three natural Norway spruce populations in the Sumava Mountains determined by isoenzyme analysis. Silva Gabreta vol.3: 173-182.

Milovanovic J., Sijacić-Nikolic M., 2010. Characterization of serbian spruce variability applying isoenzyme markers. Biotechnology \& Biotechnological Equipment 24(1): 1600-1605. DOI: 10.2478/V10133-010-0012-8.

Muller-Starck G., 1995. Genetic variation in high elevated populations of Norway spruce (Picea abies (L.) Karst.) in Switzerland. Silvae Genetica 44(5-6): 356-362.

Pârnuță Gh., 2008. Variabilitatea genetică şi ameliorarea arborilor de molid cu coroană îngustă în România [Genetic variability and tree impruvment of Norway spruce narrow tree in Romania]. Editura Silvică, Bucureşti: p. 181.

Peakall R., Smouse P.E., 2006. GENALEX 6: genetic analysis in Excel. Population genetic software for teaching and research. Molecular Ecology Notes 6(1): 288-295. DOI: $10.1111 /$ j.1471-8286.2005.01155.x.

Sabor J., Kempf M., Masternak K., 2013. Genetic structure of Norway spruce (Picea abies (L.) Karst.) provenances tested in IPTNS-IUFRO 1964/68 experiment in Krynica. Folia Forestalia Polonica, Seria A - Forestry 55 (1): 10-17. DOI: 10.2478/ffp-2013-0002.

Sequeira A.S., Confalonieri V.A., Vilardi J.C., 1997. An adaptive explanation for geographically structured allozyme variation in Dichroplus elongates (Orthoptera: Acrididae). Journal of Genetics 76(1): 33-42. DOI: 10.1007/BF02931767.

Şofletea N., Curtu L., 2007. Dendrologie [Dendrology]. Editura Universității Transilvania Braşov, 304 p.

Stănescu V., Şofletea N., 1992. Cercetări de genetică ecologică în molidişuri montane (II) [Ecological genetics research in mountains spruce stands]. Revista Pădurilor 1: 2-5.

Sulkowska M.K., 2012. Isoenzyme Analyses Tools Used Long Time in Forest Science. In: K. Gowsi (eds.): Chemistry, Analitical Chemistry, Electrophoresis. ISBN 978-953-51-0846-7.http://www.intechopen.com/ books/electrophoresis/isoenzyme-analyses-tools-usedlong-time-in-forest-science.

Teodosiu M., 2009. Molidul (Picea abies (L.) Karst.). In: G. Mihai (ed.) Surse de semințe testate pentru principalele specii de arbori forestieri din România [Seed sources tested for the mains species of forest trees in Romania]. Editura Silvică, p.184-190.

Teodosiu M., 2011. Cercetari privind variabilitatea genetica in arboretele de molid din Obcinele Bucovinei [Resarch regarding genetic variability in Norway spruce stands from Obcinele Bucovinei]. Ph. D. Thesis, Department of Forest Sciences, Transilvania University 
Radu et al.

of Braşov, $164 \mathrm{p}$.

Thompson I., Mackey B., McNulty S., Mosseler A., 2009. Forest resilience, biodiversity, and climate change. A Synthesis of the Biodiversity/Resilience/Stability in Forest Ecosystems. Secretariat of the Convention on Biological Diversity, Montreal. Technical Deries no. 43, 67 pages.

Vicario F., Vendramin G.G., Rossi P., Liò P., Giannini R., 1995. Allozyme, chloroplast DNA and RAPD markers for determining genetic relationships between Abies alba and the relict population of Abies nebrodensis. Theoretical and Applied Genetics 90(7-8): 1012-1018. DOI: $10.1007 / \mathrm{BF} 00222915$.

Yeh F.C., Yang R., 1999. Popgene Version 1.31. Department of Renewable Resources, University of Alberta.
Genetic diversity of Norway spruce [Picea abies (L.) Karst.] ...

http://www.ualberta.ca/ fyeh/popgene.pdf.

Zubizarreta G.A., Peltola H., Pulkkinen P., 2009. Growth and wood property traits in narrow crowned Norway spruce (Picea abies f. pendula) clones grown in southern Finland. Silva Fennica 43 (3): 369-382.

\section{Supporting Information}

The online version of the article includes the Supp. Info.

Table 1. Enzyme coding genes, alleles observed and their relative frequency in populations 